\title{
IMPROVING STUDENTS' CRITICAL THINKING SKILLS THROUGH ARGUMENT MAPPING-BASED GUIDED INQUIRY ON HUMAN EXCRETORY SYSTEM
}

\author{
Muhammad Jamhari \\ SMA Unggulan CT Foundation Deli Serdang \\ (e-mail: jamiedarhany1@gmail.com)
}

\begin{abstract}
Abstrak
Penelitian ini bertujuan menganalisis peningkatan kemampuan berpikir kritis siswa pada aspek fokus, dorongan dalam memberi alasan, penalaran, organisasi, konvensi dan integrasi melalui penerapan model pembelajaran inkuiri terbimbing berbasis pemetaan argumen. Jenis penelitian ini adalah penelitian tindakan kelas (PTK) yang mengadopsi model Kemmis dan McTaggart dengan siklus perencanaan, tindakan, pengamatan dan refleksi. Penelitian ini dilakukan di kelas XI-Avenzoar SMA Unggulan CT Foundation Deli Serdang pada tahun ajaran 2019/2020. Teknik pengambilan sampel dilakukan secara total sampling yang terdiri dari 24 siswa dengan komposisi 6 siswa laki-laki dan 18 siswa perempuan. Instrumen menggunakan tes uraian yang diadaptasi dari Finken berdasarkan Illinois Critical Thinking Essay Test dan pemetaan argumen yang diadaptasi dari van Gelder pada konsep sistem ekskresi manusia. Metode pengumpulan data melalui wawancara, observasi dan dokumentasi. Seluruh data dikerjakan dengan analisis deskriptif yang dikembangkan oleh Miles dan Huberman, yaitu reduksi data, presentasi data dan gambaran kesimpulan. Hasil menunjukkan bahwa aspek fokus dan penalaran dari tes kemampuan berpikir kritis pada siklus I memperoleh skor tertinggi, sedangkan pada aspek dorongan dalam memberi alasan dan konvensi memperoleh skor terendah dan tidak menunjukkan adanya peningkatan. Sementara itu pada Siklus II, aspek fokus dan penalaran meningkat secara signifikan dan memperoleh nilai tertinggi. Akan tetapi, aspek dorongan dalam memberi alasan meningkat secara bertahap, namun konvensi tetap. Hal ini menunjukkan bahwa terdapat peningkatan yang signifikan antara kelompok pada Siklus I (65.42) dan Siklus II (80.21) dari skor rata-rata kemampuan berpikir kritis siswa melalui penilaian pemetaan visual. Aspek pemetaan argumen, seperti tuntutan, alasan, bantahan, penolakan, dan perdebatan meningkat dengan baik diantara kedua siklus. Hal ini menyatakan bahwa pemetaan argumen dapat meningkatkan kemampuan berpikir kritis siswa dalam Biologi. Dari hasil dan pembahasan, dapat disimpulkan bahwa penerapan model pembelajaran inkuiri terbimbing berbasis pemetaan argumen pada konsep sistem ekskresi manusia memiliki peningkatan yang sangat positif dan signifikan terhadap kemampuan berpikir kritis siswa. Kemampuan berpikir kritis siswa berada pada kategori tinggi.
\end{abstract}

Kata Kunci: Kemampuan berpikir kritis, inkuiri terbimbing berbasis pemetaan argumen, penelitian tindakan kelas, sistem ekskresi manusia.

\begin{abstract}
This study aims to analyze the improvement of students' critical thinking skills in the features of focus, supporting reasons, reasoning, organization, conventions and integration through the implementation of argument mapping-based guided inquiry learning models. Type of this research is classroom action research, a systematic inquiry with the goal of informing practice in particular situation which adopted Kemmis and McTaggart's models which follows the cycle of planning, action, observation and reflection. It was conducted in class XI-Avenzoar of SMA Unggulan CT Foundation Deli Serdang in the academic year 2019/2020. The sampling technique was done by total sampling consisting of 24 students with a composition of 6 boys and 18 girls. The instrument used the essay tests adapted from Finken based on Illinois Critical Thinking Essay Test and argument mapping based on van Gelder on the concept of human excretory system. The data collection methods were included the
\end{abstract}


interview, observation and documentation. The whole data was employed by descriptive analysis developed by Miles and Huberman which includes three concurrent activities, data reduction, data presentation and conclusion drawing. The results showed that the features of focus and reasoning from critical thinking skills tests in Cycle I obtained the highest score of all, while the features of supporting reasons and conventions obtained the lowest score and showed no improvement at all. Meanwhile in Cycle II, the features of focus and reasoning increased significantly and obtained the highest score as well. However, the feature of supporting reasons increased simultaneously but conventions still remained. It definitely showed that there was a significant improvement between groups in Cycle I (65.42) and Cycle II (80.21) from the average score of students' critical thinking skills through their argument mapping grading. The aspects of argument mapping, such as claims, reasons, objections, rebuttals and debates improved well between these cycles. It was strongly suggested that argument mapping could enhance students' critical thinking skills in Biology. From the results and discussion, it could be concluded that the implementation of the argument mapping-based guided inquiry learning models on the concept of human excretory system had a very positive and significant improvement on students' critical thinking skills. The students' critical thinking skills were in the high category.

Keywords: Critical thinking skills, argument mapping-based guided inquiry, classroom action research, human excretory system.

\section{Introduction}

Education is the process of developing the capacities and potentials of the individual so as to prepare that individual to be successful in a specific society or culture. The world is becoming more and more competitive, quality of performance has been the key factor for personal progress. Parents desire that their children climb the ladder of performance to as high a level as possible. This desire for a high level of achievement puts a lot of pressure on students, teachers, schools and in general education system itself. School achievement may be affected by various factors like intelligence, study habits, and attitude of people towards school, different aspects of their personality, and socio-economic status.

An emphasis on understanding leads to one of the primary characteristics of the new science of learning: its focus on the processes of knowing [1];[2]. Humans are viewed as goal-directed agents who actively seek information. They come to formal education with a range of prior knowledge, skills, beliefs, and concepts that significantly influence what they notice about the environment and how they organize and interpret it. This, in turn, affects their abilities to remember, reason, solve problems, and acquire new knowledge.

There is widespread acceptance of the idea that critical thinking should be an important dimension of science education. Thus, for example, the [3] as one of its goals has the promotion of science as inquiry. The work in the science education literature devoted to the fostering of critical thinking takes a number of different forms. Some of it focuses on particular aspects of critical thinking, for example identifying logical fallacies [4];[5]; formal reasoning [6];[7],[8];[9]; and scientific reasoning more broadly [10]. Most often it is directed to either the description and evaluation of projects and programmes aimed at fostering critical thinking [11];[12];[13];[14];[15] or the assessment of students' abilities to think critically [4];[6].

Critical thinking includes the ability to respond to material by distinguishing between facts and opinions or personal feelings, judgments and inferences, inductive and deductive arguments, and the objective and subjective. It also includes the ability to generate questions, construct, and recognize the structure of arguments, and adequately support arguments; define, analyze, and devise solutions for problems and issues; sort, organize, classify, correlate, and analyze materials and data; integrate information and see relationships; evaluate information, materials, and data by drawing inferences, arriving at reasonable and informed conclusions, applying understanding and knowledge to new and different problems, developing rational and reasonable interpretations, suspending beliefs and remaining open to new information, methods, cultural systems, values and beliefs and by assimilating information. In its exemplary form, it is based on universal intellectual values that transcend subject matter divisions: clarity, accuracy, precision, consistency, relevance, sound evidence, good reasons, depth, breadth, and fairness.

Critical thinking can be taught. Teaching it involves breaking down the process or thinking of it 
as a number of steps. Each step needs to be explained and practiced explicitly and students given opportunity for undertaking this practice as part of formative assessment [16]. The academic needs to take the role of facilitator in supporting students to develop an explicit understanding of the critical thinking process. They then need to allow students time to practice and to receive feedback [17].

An effective learning model to overcome students' low critical thinking skills is inquiry learning. Inquiry learning is a learning with a series of activities that emphasize the process of thinking critically and analytically to find out for themselves the answers to a questioned problem [18]. It's one of the innovative learning methods that is appropriate for use in science learning, because students can be actively involved in the learning process to systematically search and investigate [19]. It does not only require students to master the subject matter, but how they can use their potential [20]. The results of previous studies conducted by [21] and [22] state that there is an increase in students' critical thinking skills in the classes applied in inquiry learning. Inquiry learning requires students to identify and assume, use critical thinking, logically, and considerations of explanation [23].

Inquiry learning is divided into four levels based on the level of openness and cognitive demands needed. The simplest level of inquiry, namely (1) structured inquiry; (2) guided inquiry; (3) open inquiry; (4) learning cycle [24]. Seeing the subject is eleventh grade senior high school students, the right type of inquiry is guided inquiry. Guided inquiry is used for students who are less experienced in inquiry learning [25].

Guided inquiry is a learning where the teacher gives problems and investigation procedures, while students in groups determine the investigation process and conclude [26]. It also allows students to move step by step from identifying problems that define hypothetical problem formulation, data collection, verification of results, and generalization to the conclusion of conclusions [27]. The role of the teacher during the guided inquiry learning process is as a nursery and facilitator. The stages of inquiry learning used in this research are: (1) investigating a phenomenon; (2) focusing on questions: (3) planning investigations; (4) investigations; (5) analyze data and evidence; (6) building new knowledge; and (7) communicating new knowledge [28].

The means of representing ideas in diagrams with node-link assemblies has been termed concept mapping [29], mind mapping [30] and argument mapping [31]. All of these mapping techniques are called visual mapping [32]. However, the author only emphasized argument mapping as the main mapping technique to increase students' critical thinking skills integrated with guided inquiry. When used as a part of instruction, this type of mapping technique has been shown to increase students' achievement scores [33], enhance knowledge retention [34], and develop critical thinking skills [35];[36];[37].

[38] stated that students should assume the role of a scientist by developing concepts and gathering knowledge to support those concepts. According to [39], suggested that in many classrooms, science instruction does not support the need for developing student to inquiry scientific investigations. What students gain as a result of the study of science through real life critical thinking skills and understanding the world need to increase as well as their scores in the end of the year tests. [40] observed that science should be taught and learned through visualization. Activities in science classroom should involve the critical thinking aspects. Argument mapping is seen as a system of learning that supports the development of students' critical thinking skills.

Argument mapping involves clearly outlining a contention at the top of a map, followed by tiers of reasons and objections. Argument mapping can be augmented with computer-aided argument mapping software that aids the mapping process. Argument mapping can be used in any discipline because every discipline deals with arguments. An example argument map is shown in Figure 1. 


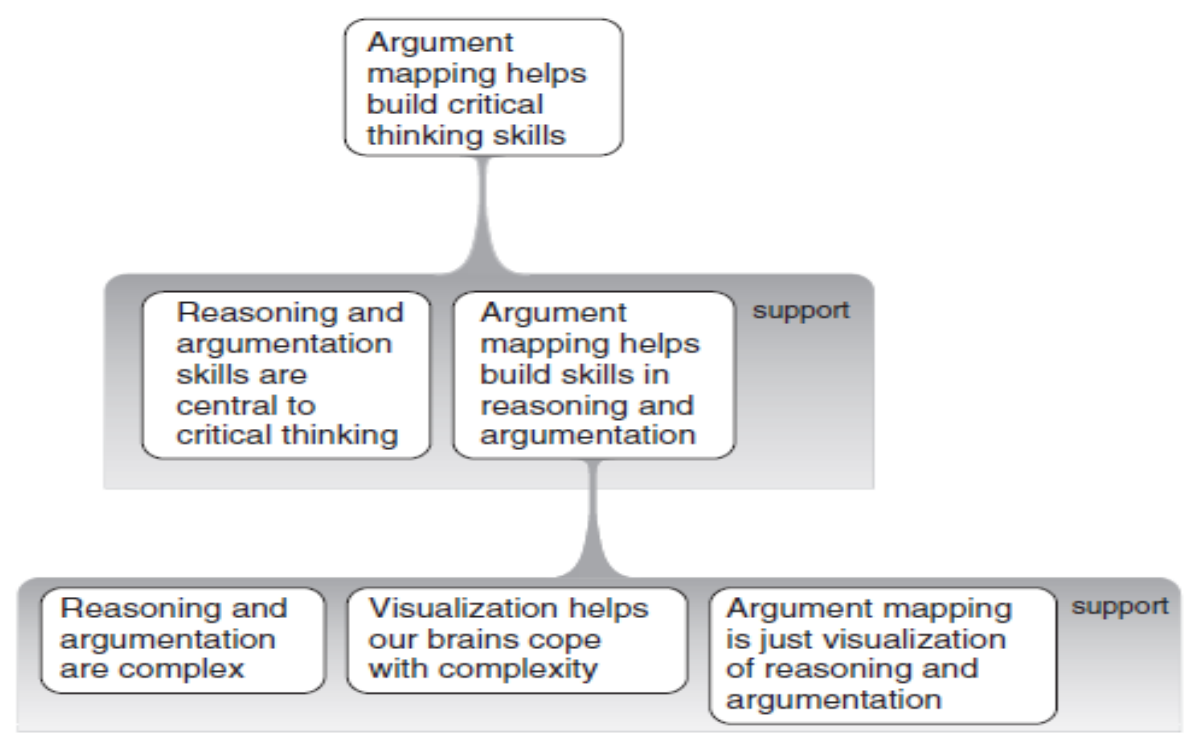

Figure 1. A map of an argument for the proposition that argument mapping helps build critical thinking skills. Map produced using the Rationale software (Source: [41])

An argument map is a claim, contention or proposition together with the set of reasons and evidence put forward to support that claim, contention or proposition. Complex argument maps can also include objections and rebuttals, each of which are themselves arguments, that is, claims with supporting evidence and reasoning. However, that there does not need to be any disagreement about the evidence and reasoning for a writer to present an argument. Since the justified answer to a question constitutes an argument, framing students' writings around them and their target readers' questions is an effective approach to developing arguments. To figure out how to assess the argument mapping technique, it will be presented in Table 1 .

Table 1. Grading Rubric of Argument Mapping

\begin{tabular}{|c|c|c|c|c|}
\hline & Beginning & $\begin{array}{c}\text { Emerging } \\
\text { Understanding }\end{array}$ & $\begin{array}{c}\text { Developing } \\
\text { Understanding }\end{array}$ & $\begin{array}{c}\text { Good } \\
\text { Understanding }\end{array}$ \\
\hline $\begin{array}{l}\text { Author's } \\
\text { main } \\
\text { argument }\end{array}$ & $\begin{array}{l}\text { Map outlines } \\
\text { ideas that are } \\
\text { not yet } \\
\text { visibly } \\
\text { connected to } \\
\text { the author's } \\
\text { argument or } \\
\text { goal. }\end{array}$ & $\begin{array}{l}\text { Map outlines } \\
\text { key ideas } \\
\text { without yet } \\
\text { accurately } \\
\text { identifying the } \\
\text { author's } \\
\text { argument. }\end{array}$ & $\begin{array}{l}\text { Map accurately } \\
\text { outlines } \\
\text { author's goal \& } \\
\text { argument } \\
\text { One of the } \\
\text { following are } \\
\text { missing or } \\
\text { unclear: } \\
\text { - type of } \\
\text { argument } \\
\text { - paraphrased } \\
\text { text }\end{array}$ & $\begin{array}{l}\text { Map accurately } \\
\text { outlines (i) } \\
\text { author's goal \& } \\
\text { argument; (ii) } \\
\text { type of argument. } \\
\text { Succinct \& clear } \\
\text { paraphrasing \& } \\
\text { cited. }\end{array}$ \\
\hline
\end{tabular}




\begin{tabular}{|c|c|c|c|c|}
\hline & Beginning & $\begin{array}{c}\text { Emerging } \\
\text { Understanding }\end{array}$ & $\begin{array}{c}\text { Developing } \\
\text { Understanding }\end{array}$ & $\begin{array}{c}\text { Good } \\
\text { Understanding }\end{array}$ \\
\hline $\begin{array}{l}\text { Main ways } \\
\text { the author } \\
\text { supports } \\
\text { his/her } \\
\text { argument }\end{array}$ & $\begin{array}{l}\text { Map } \\
\text { identifies } \\
\text { many details } \\
\text { most of } \\
\text { which are } \\
\text { not clearly } \\
\text { connected to } \\
\text { the } \\
\text { argument. }\end{array}$ & $\begin{array}{l}\text { Map identifies m } \\
\text { details, only som } \\
\text { clearly connected } \\
\text { argument. }\end{array}$ & $\begin{array}{l}\text { ny interesting } \\
\text { of which are } \\
\text { o the authors? }\end{array}$ & $\begin{array}{l}\text { Map selectively } \\
\text { identifies key } \\
\text { details author } \\
\text { uses to make } \\
\text { argument \& cited } \\
\text { page numbers. }\end{array}$ \\
\hline $\begin{array}{l}\text { Symbolically } \\
\text { and spatially } \\
\text { represent } \\
\text { the } \\
\text { argument }\end{array}$ & $\begin{array}{l}\text { Unorganized } \\
\text { map. No } \\
\text { clear use of } \\
\text { space, } \\
\text { symbol or } \\
\text { color. }\end{array}$ & $\begin{array}{l}\text { Uses space, } \\
\text { symbol or color } \\
\text { without yet } \\
\text { representing the } \\
\text { type argument. }\end{array}$ & $\begin{array}{l}\text { Organized map } \\
\text { that carefully } \\
\text { uses space, } \\
\text { symbol or } \\
\text { color. Needs a } \\
\text { little clarifying } \\
\text { to fully } \\
\text { communicate } \\
\text { type of } \\
\text { argument }\end{array}$ & $\begin{array}{l}\text { Organized map } \\
\text { that purposefully } \\
\text { uses space, } \\
\text { symbol \& color } \\
\text { to communicate } \\
\text { type of argument }\end{array}$ \\
\hline \multicolumn{5}{|c|}{ Three questions clearly stimulated by text } \\
\hline \multicolumn{5}{|c|}{$\begin{array}{l}\text { Key phrases/concepts that seem important to } \\
\text { understand }\end{array}$} \\
\hline \multicolumn{3}{|c|}{$\begin{array}{l}\text { Passage that you'd like to understand better } \\
\text { and that would be interesting/useful to discuss }\end{array}$} & & \\
\hline \multicolumn{3}{|c|}{ Any errors in logic or weak warrants? } & & \\
\hline
\end{tabular}

(Source: [42])

Educators are looking for new ways to make their teaching engaging, active, and student-centered can use visual mapping tools to achieve their teaching and learning goals. Teachers can visually engage students by making maps that complement or take the place of written information. They can also have their students participate in the tactile activity of making maps. Active learning occurs when "students are doing things and thinking about what they are doing" and meaningful learning happens when students integrate new information into what they already know [43];[44]. Visual mapping, which requires students to express their understanding of concepts in words and images and then draw and label links between those ideas, facilitates both learning processes.

The results of previous studies state that pre- and post-test studies have demonstrated the pedagogical benefit of argument mapping using cohorts of high school students and intelligence analysts as subjects, and by comparing argument mapping interventions with data from comparison groups or benchmarks from other meta-analytic reviews. It has been found that intensive practice mapping arguments with the aid of software has a strong positive effect on the critical thinking ability of students. Meta-analysis has shown that high-intensity argument mapping courses improve critical thinking scores by around 0.8 of a standard deviation-more than twice the typical effect size for standard critical thinking courses [31]. This strongly suggests that argument mapping is a very effective way to teach critical thinking. 
In fact, critical thinking skills of eleventh grade students in SMA Unggulan CT Foundation on the concept of human excretory system were also declined because they were not actively involved in learning activity [45]. The learning processes occured in schools were mostly based on a teachercentered instruction. It was also stated that science education has, in many cases, become teacher centered, based on rote memorization, and focused on test scores [46];[47];[37];[48]. Most students considered science to be boring, a list of big words and facts, intimidating, and not relevant to their lives [48].

This study aims to analyze the improvement of students' critical thinking skills in aspects of elementary clarification, basic support, inference, advance clericalation, strategies and tactics through the implementation of argument mapping-based guided inquiry learning models. Theoretically, this study contributes conceptually to the progress and development of learning in schools, especially the improvement of critical thinking skills.

\section{Methods}

Type of this research is classroom action research, a systematic inquiry with the goal of informing practice in particular situation [49]. This study adopted Kemmis and McTaggart's models which follows the cycle of planning, action, observation and reflection. Planning involves the determination of the question that needs answering and the strategy to be used in answering it. During the action stage, the practitioner tries out the strategy. The observation stage includes recording data on the result of the strategy and also keeping a journal on the practitioner's thoughts and reactions to the entire experience. Finally, during the reflection stage, the researcher makes conclusions so that a new cycle can begin [50]. This study was conducted in class XI-Avenzoar of SMA Unggulan CT Foundation Deli Serdang in the academic year 2019/2020. The sampling technique was done by total sampling consisting of 24 students with a composition of 6 boys and 18 girls. The instrument used the essay tests adapted from [51], based on Illinois Critical Thinking Essay Test and argument mapping based on [41] on the concept of human excretory system. The data collection methods were included the interview, observation and documentation. The whole data was employed by descriptive analysis developed by [52] which includes three concurrent activities, data reduction, data presentation and conclusion drawing.

\section{Stages of Intervention Actions}

\section{Pre-Research Preparation}

Field orientation through observation, interviews and classroom teaching with students on the concept of human excretory system in class XI-Avenzoar of SMA Unggulan CT Foundation Deli Serdang to analyze the problems faced in the biology learning process before this class action research would be conducted. Subsequently, the researcher discussed the results of the study by determining the focus of the problem to be examined with mentors, experts and peers. Finally, the researcher reviewed the literatures as well as the results of relevant studies.

2. Cycle I

a. Stages of Action Planning

1) Planning the learning instruction that will be applied in the teaching and learning process.

2) Designing strategies and learning scenarios that will be implemented using argument mapping-based guided inquiry learning models.

3) Determineing the indicators of success in learning.

4) Arranging research instruments for the process of data collection consisting of the essay critical thinking tests, argument mapping on the concept of human excretory system and observation sheets. For the test instrument, it is based on Illinois Critical Thinking Essay Test to assess students critical thinking skills.

5) Determining the focus of observation and aspects to be observed as a guide to the observation sheets.

b. Stages of Action Implementation 
1) The teacher gives an explanation of the learning objectives that will be given to students.

2) The teacher conducts learning activities by using the argument mapping-based guided inquiry learning models.

3) The teacher gives a pre-test before learning process and a post-test after learning process with an argument mapping-based guided inquiry learning models.

c. Stages of Action Observation

1) The researcher records all data and information about students' critical thinking skills that can be seen directly during learning in accordance with the observation sheets.

2) The teacher as a researcher records his activities in carrying out the learning processes with an argument mapping-based guided inquiry learning models based on the teacher's note sheet.

3) The researcher conducts discussions with mentors and peers about activities that have already occurred.

d. Reflection of Cycle I

The researcher conducts the evaluation of the action by analyzing all the data obtained in Cycle I. Based on the observations of all the activities that have been carried out, then the analysis, meaning, explanation and conclusion of the data are measured. The conclusion obtained in the form of the effectiveness of the learning design made and a list of problems and constraints overcome in the field. These results are then used as a basis for planning in Cycle II.

\section{Results and Discussion}

Based on observations during the learning process that occurred, there are some records that can be seen in Table 1 .

Table 1. The Results of Field Records in Cycles I and II

\begin{tabular}{|c|c|c|c|}
\hline \multirow[t]{2}{*}{ NO. } & \multirow{2}{*}{$\begin{array}{l}\text { OBSERVATION } \\
\text { INDICATOR }\end{array}$} & \multicolumn{2}{|c|}{ STUDENT CONDITIONS PER GROUPS } \\
\hline & & CYCLE I & CYCLE II \\
\hline 1. & Learning in groups & $\begin{array}{l}\text { - Start conditioned. } \\
\text { - Some are still making jokes and } \\
\text { not serious in receiving the } \\
\text { instruction. }\end{array}$ & $\begin{array}{l}\text { - Well grouped. } \\
\text { - Being in a predetermined } \\
\text { position. } \\
\text { - Ready to discover and find } \\
\text { out. }\end{array}$ \\
\hline 2. & $\begin{array}{l}\text { Proposing the } \\
\text { questions or answers }\end{array}$ & $\begin{array}{l}\text { - Still hesitant in delivering } \\
\text { answers. } \\
\text { - In general students want to } \\
\text { answer if appointed by the } \\
\text { teacher. } \\
\text { - There are still many students } \\
\text { who do not listen to their } \\
\text { friends who are delivering } \\
\text { answers. }\end{array}$ & $\begin{array}{l}\text { - Confident when expressing } \\
\text { opinions and answers to } \\
\text { other groups. } \\
\text { - Able to respect the opinions } \\
\text { of others, accept advices at } \\
\text { all times and listen to any } \\
\text { questions given. }\end{array}$ \\
\hline 3. & Discussion in groups & $\begin{array}{l}\text { - Dominated by smart students. } \\
\text { - Some students only rely on } \\
\text { their friends. } \\
\text { - Most of them are still looking } \\
\text { shy in expressing opinions. } \\
\text { - Some are passive and } \\
\text { following their friends' } \\
\text { opinions. } \\
\text { - They begin to ask and discuss. }\end{array}$ & $\begin{array}{l}\text { - Groups and class } \\
\text { discussions start very } \\
\text { actively. } \\
\text { - All group members share } \\
\text { their opinions and respect } \\
\text { each other's opinions. }\end{array}$ \\
\hline
\end{tabular}


Based on Table 1, it could be seen that learning by groups in Cycle I made students begin to be conditioned to carry out the learning activities, there were still some students who were still making jokes, gathering with other groups. Some groups still had passive members. At the time of question and answer it appeared students were still hesitant in conveying the answers. They only wanted to answer when they had been appointed by the teacher. This was caused that many students who did not listen to their friends who were delivering their answers because they felt they had no assignment to answer questions. This caused the question and answer process had not gone well. During the learning discussion, it was apparent that students began discussing with their group friends. But it was still dominated by smart students.

Students who were passive following only the opinions of their friends who were considered smart. They were still shy and afraid to express their opinions or answers. Some students also still relied on others in the worksheet.

In the learning group of Cycle II looked more smooth. Students were well conditioned, and eager to start learning. When asking questions or answers, all students were active and confident in answering or asking questions. All students listened and respected the group presenting their group's results. During the group discussion all students were actively involved in the course of discussion. They began to appreciate friends who have given opinions or asked questions, and exchanged ideas in solving problems raised.

The observations of students' critical thinking skills are portrayed in Table 2.

Table 2. The Results of Observation in Students' Critical Thinking Skills

\begin{tabular}{|c|c|c|c|}
\hline No. & $\begin{array}{l}\text { Features of Critical Thinking Skills } \\
\text { (Finken Et Al., 1993) }\end{array}$ & $\begin{array}{l}\text { Percentage of } \\
\text { Cycle I }\end{array}$ & $\begin{array}{l}\text { Percentage of } \\
\text { Cycle Ii }\end{array}$ \\
\hline 1. & $\begin{array}{l}\text { FOCUS } \\
\text { Degree to which main idea/theme or point of view is } \\
\text { clear and maintained. }\end{array}$ & $81.50 \%$ & $88.68 \%$ \\
\hline 2. & $\begin{array}{l}\text { SUPPORTING REASONS } \\
\text { Degree to which supporting reasons and evidence are } \\
\text { clear, believable, and from credible sources. }\end{array}$ & $60.25 \%$ & $62.25 \%$ \\
\hline 3. & $\begin{array}{l}\text { REASONING } \\
\text { Degree to which conclusion supported by reasons/ } \\
\text { evidence; alternatives addressed; and argument } \\
\text { clear. }\end{array}$ & $78 \%$ & $85 \%$ \\
\hline 4. & $\begin{array}{l}\text { ORGANIZATION } \\
\text { Degree to which logical flow of ideas and } \\
\text { explicitness of the place are clear and connected. }\end{array}$ & $70.25 \%$ & $73.50 \%$ \\
\hline 5. & $\begin{array}{l}\text { CONVENTIONS } \\
\text { Use of conventions of standard English. }\end{array}$ & $40.50 \%$ & $40.50 \%$ \\
\hline 6. & INTEGRATION & $73.85 \%$ & $77.50 \%$ \\
\hline
\end{tabular}

Based on table 2, it could be inferred that in Cycle I the percentage of critical thinking skills tests that appeared during learning in Cycle 1. It apparently showed that the features of focus and reasoning obtained the highest score of all, while the features of supporting reasons and conventions obtained the lowest score and showed no improvement at all.

Meanwhile in the Cycle II, the features of focus and reasoning increased significantly and obtained the highest score as well. However, the feature of supporting reasons increased simultaneously but conventions still remained. 
The data of the argument mapping grading can be presented in Table 3.

Table 3. The Results of the Students' Argument Mapping Grading

\begin{tabular}{|c|c|c|c|c|c|c|c|c|c|c|c|c|c|c|c|}
\hline \multirow[t]{2}{*}{ NO } & \multirow{2}{*}{$\begin{array}{l}\text { Name } \\
\text { Code }\end{array}$} & \multicolumn{2}{|c|}{ Claims } & \multicolumn{2}{|c|}{ Reasons } & \multicolumn{2}{|c|}{ Objections } & \multicolumn{2}{|c|}{ Rebuttals } & \multicolumn{2}{|c|}{ Debates } & \multicolumn{2}{|c|}{ Score } & \multicolumn{2}{|c|}{ Grade } \\
\hline & & I & II & I & II & I & II & I & II & I & II & I & II & I & II \\
\hline 1. & AM-1 & 3 & 3 & 2 & 3 & 3 & 3 & 3 & 4 & 3 & 4 & 14 & 17 & 70 & 85 \\
\hline 2. & AM-2 & 2 & 3 & 3 & 3 & 3 & 4 & 2 & 3 & 3 & 4 & 13 & 17 & 65 & 85 \\
\hline 3. & AM-3 & 3 & 3 & 2 & 3 & 2 & 4 & 2 & 3 & 2 & 3 & 11 & 16 & 55 & 80 \\
\hline 4. & AM-4 & 4 & 4 & 3 & 4 & 2 & 3 & 3 & 4 & 3 & 3 & 15 & 18 & 75 & 90 \\
\hline 5. & AM-5 & 3 & 3 & 3 & 3 & 3 & 4 & 2 & 3 & 3 & 4 & 14 & 17 & 70 & 85 \\
\hline 6. & AM-6 & 2 & 3 & 1 & 2 & 3 & 3 & 2 & 3 & 2 & 2 & 10 & 13 & 50 & 65 \\
\hline 7. & AM-7 & 3 & 3 & 2 & 3 & 3 & 4 & 2 & 3 & 3 & 4 & 13 & 17 & 65 & 85 \\
\hline 8. & AM-8 & 3 & 3 & 3 & 3 & 3 & 4 & 3 & 3 & 3 & 3 & 15 & 18 & 75 & 90 \\
\hline 9. & AM-9 & 3 & 3 & 2 & 4 & 3 & 3 & 4 & 4 & 4 & 4 & 16 & 18 & 80 & 90 \\
\hline 10. & AM-10 & 2 & 4 & 2 & 3 & 3 & 3 & 2 & 3 & 3 & 4 & 12 & 17 & 60 & 85 \\
\hline 11. & AM-11 & 1 & 3 & 2 & 3 & 2 & 2 & 1 & 2 & 2 & 2 & 8 & 12 & 40 & 60 \\
\hline 12. & AM-12 & 3 & 3 & 3 & 3 & 2 & 3 & 3 & 4 & 3 & 3 & 14 & 16 & 70 & 80 \\
\hline 13. & AM-13 & 2 & 3 & 3 & 3 & 3 & 3 & 2 & 3 & 3 & 3 & 13 & 15 & 65 & 75 \\
\hline 14. & AM-14 & 4 & 4 & 3 & 4 & 4 & 4 & 3 & 4 & 3 & 4 & 17 & 20 & 85 & 100 \\
\hline 15. & AM-15 & 3 & 3 & 3 & 3 & 3 & 3 & 3 & 3 & 2 & 3 & 14 & 15 & 70 & 75 \\
\hline 16. & AM-16 & 2 & 2 & 2 & 2 & 2 & 2 & 3 & 3 & 1 & 1 & 10 & 10 & 50 & 50 \\
\hline 17. & AM-17 & 3 & 4 & 2 & 2 & 3 & 3 & 3 & 4 & 3 & 4 & 14 & 17 & 70 & 85 \\
\hline 18. & AM-18 & 1 & 2 & 3 & 3 & 2 & 3 & 3 & 3 & 3 & 4 & 12 & 15 & 60 & 75 \\
\hline 19. & AM-19 & 3 & 3 & 3 & 4 & 2 & 4 & 3 & 3 & 3 & 4 & 14 & 18 & 70 & 90 \\
\hline 20. & AM-20 & 2 & 3 & 3 & 4 & 3 & 3 & 4 & 4 & 3 & 3 & 15 & 17 & 75 & 85 \\
\hline 21. & AM-21 & 3 & 4 & 2 & 3 & 2 & 2 & 3 & 3 & 3 & 3 & 13 & 15 & 65 & 75 \\
\hline 22. & AM-22 & 3 & 4 & 3 & 4 & 4 & 4 & 2 & 3 & 2 & 4 & 14 & 19 & 70 & 95 \\
\hline 23. & AM-23 & 2 & 2 & 2 & 2 & 3 & 3 & 1 & 2 & 2 & 2 & 10 & 11 & 50 & 55 \\
\hline 24. & AM-24 & 3 & 3 & 3 & 4 & 3 & 4 & 2 & 3 & 2 & 3 & 13 & 17 & 65 & 85 \\
\hline & & & & & & & & & & & & & & 1570 & 1925 \\
\hline & & & & & & & & & & & & & & 65.42 & 80.21 \\
\hline
\end{tabular}

Based on table 3, it could be inferred that in Cycle I the average score of students' critical thinking skills through their argument mapping grading was 65.42. Meanwhile, the average score of their critical thinking skills through argument mapping grading was 80.21 in Cycle II. It definitely showed that there was a significant improvement between groups in Cycle I and Cycle II. The aspects of argument mapping, such as claims, reasons, objections, rebuttals and debate improved well between these cycles. It was strongly suggested that argument mapping as one of the most effective visual mappings could enhance students' critical thinking skills in Biology. Eventhough, there were still students who really needed much time to develop and master their argument mapping because it was still brand new to their own understanding. The data of the interviews can be seen in Table 4 . 
Table 4. The Results of the Students' Interviews

\begin{tabular}{|c|c|c|c|}
\hline No. & Questions & No & Yes \\
\hline 1. & Do you experience difficulties during the learning process? & $78.46 \%$ & $21.54 \%$ \\
\hline 2. & $\begin{array}{l}\text { Do you think the learning process that has been taught is } \\
\text { interesting? }\end{array}$ & $7.62 \%$ & $92.38 \%$ \\
\hline 3. & $\begin{array}{l}\text { Do you think the learning process that has been done can improve } \\
\text { understanding of the concepts of human excretory system? }\end{array}$ & $24.32 \%$ & $75.68 \%$ \\
\hline 4. & Is the learning activity able to stimulate you to think critically? & $15.60 \%$ & $84.40 \%$ \\
\hline 5. & Has the learning been carried out effectively? & $21.38 \%$ & $78.62 \%$ \\
\hline 6. & $\begin{array}{l}\text { Do you have the skills to think critically after doing learning } \\
\text { activities? }\end{array}$ & $21 \%$ & $79 \%$ \\
\hline 7. & $\begin{array}{l}\text { Do you like learning biology with the argument mapping-based } \\
\text { guided inquiry learning models? }\end{array}$ & $6.52 \%$ & $93.48 \%$ \\
\hline 8. & $\begin{array}{l}\text { Do you think that argument mapping is difficult to develop } \\
\text { instead of concept mapping and mind mapping? }\end{array}$ & $83.60 \%$ & $16.40 \%$ \\
\hline
\end{tabular}

From the results of structured interviews with students in Cycle I, it could be inferred that students who experienced difficulties in the learning process by $21.54 \%$. They suggested that they were not familiar with the learning process employed. In the second question it was found that $7.62 \%$ of students felt that the learning process was less interesting, however $92.38 \%$ of students felt that the learning process was interesting because the models were very interactive. The third question was obtained by $75.68 \%$ of students who felt the understanding of the concept improved after learning, they stated that they were really motivated to practice what they were learning and tried to find out what concepts existed in the learning activities. Meanwhile students who felt the understanding of the concept did not increase that only a few concepts can be absorbed. In the fourth question it was known that $84.40 \%$ of students who were motivated to think critically according to their ongoing learning eventually made them ask themselves and then practiced it out of curiosity. The fifth question was known to be $78.62 \%$ who agreed that learning process run effectively and the rest of them were disagree. The sixth question was known that $79 \%$ of students think critically after doing learning activities and $21 \%$ don't either. The subsequent question obtained by $93.48 \%$ of students liked the argument mapping-based guided inquiry and only $6.52 \%$ of students who did not like the learning models. Last but not least, the students felt that the argument mapping was not difficult to develop instead of concept and mind mapping as well. Eventhough, argument mapping was very novel to their initial comprehension, however the more it was introduced and practiced, the more they understood the benefits for their critical thoughts.

The application of biology learning by applying the argument mapping-based guided inquiry learning models on the concept of human excretory system could increase the effectiveness of learning process. Prior to the implementation of learning using the integrated models, the learning process was not fully student-centered. Students have not been actively involved in participating in all learning activities. After carrying out learning activities using argument mapping-based guided inquiry, they were more active in participating in learning, the teacher did not dominate the class anymore, they were also able to learn independently.

In cycle I, the average achievement of students' critical thinking skills as a whole after the learning process was carried out applying the argument-mapping-based guided inquiry models on subconcept of the process of urine formation (filtration, reabsorpsion and secretion phase) was $76.45 \%$ with mastery learning reaching $83.62 \%$.

In cycle II, the average achievement of students' critical thinking skills as a whole after applying the argument mapping-based guided inquiry on the sub-concept of of the process of urine formation (filtration, reabsorpsion and secretion phase) was $84.45 \%$ with mastery learning achieving an ideal completeness of $91.74 \%$. This showed a significant increase in mastery of students' critical thinking skills from Cycle I to Cycle II. In accordance with the theoretical study suggested that the guided inquiry learning models is designed to encourage students' learning activities following observation, 
measurement, estimation, prediction, comparing, classification, experiments, communication, inference, analysis and making conclusions as a feature of inqury with the integration of argument mapping as one of the most effective visual mappings in enhancing students' critical thinking skills.

The characteristics of guided inquiry learning can be seen and measured through student activities in students' critical thinking skills. The guided inquiry process puts the emphasis on scientist in "student-scientist". The primary objective of guided inquiry is to promote learning through student investigation. This material is designed to assist teachers in targeting critical thinking skills and higherorder thinking for their students [53].

Guided inquiry and argument mapping, a process important at all grade levels requires students to engage in critical thinking skills of summarizing, analyzing and evaluating as well as focus, supporting reasons, reasoning, organization, conventions and integration. Teachers use guided inquiry models to promote learning through student investigation, following the same process used by scientists. By using data sets from working scientists, students focus their efforts on analysis and evaluation. These activities mirror scientific methods and critical thoughts that lead to more questions and additional research [54].

Argument mapping enthusiasts believe that it has numerous potential benefits. For the suitably skilled person, mapping a complex argument promotes clarity and insight, more rigorous and complete articulation, and more judicious evaluation. Teachers use argument mapping to help students acquire basic concepts, better understand how arguments are constructed, and enhance their reasoning skills. Argument mapping can be an effective way to improve general critical thinking skills. In the workplace, argument mapping can promote rational resolution in complex, fractious debates; improved communication of important arguments; and better decision making [31].

\section{Conclusion}

Based on the results and discussion of the study, it could be concluded that the implementation of the argument mapping-based guided inquiry learning models on the concept of human excretory system had a very positive and significant improvement on students' critical thinking skills in Class XIAvenzoar at SMA Unggulan CT Foundation Deli Serdang. The critical thinking skills that have improved were the features of focus, supporting reasons, reasoning, organization, conventions and integration. The students' critical thinking skills were in the high category.

Student responses to the application of argument mapping-based guided inquiry in the learning process of the concept of human excretory system were very positive. Students agreed to learn in this way was interesting, not boring and invited to increase learning activities and critical thinking abilities. Students come to understand how to improve their critical thinking skills through argument mappingbased guided inquiry learning models.

\section{References}

[1] Piaget, J. Success and Understanding. London: Routledge \& Kegan Paul. 1978.

[2] Vygotsky, L.S. Mind In Society: The Development of Higher Psychological Processes. Cambridge: Harvard University Press. 1978.

[3] National Academy of Sciences. National Science Education Standards, National Academy Press: Washington, DC. 1996.

[4] Dreyfus, A., E. Jungwirth. Students' Perceptions of the Logical Structure of Curricular as Compared with Everyday Contexts-Study of Critical Thinking Skills', Science Education, 64(3): 309-321. 1980.

[5] Jungwirth, E., A. Dreyfus. Diagnosing the Attainment of Basic Inquiry Skills: The 100-year Old Quest for Critical Thinking. Journal of Biological Education, 24(1): 42-49. 1990.

[6] Garnett, J.P., K.G. Tobin. Reasoning Patterns of Preservice Elementary and Middle School Science Teachers, Science and Education, 68(5): 621-631. 1984. 
[7] Lawson, A.E. The Nature of Advanced Reasoning and Science Instruction, Journal of Research in Science Teaching, 19(9): 743-759. 1982.

[8] Lawson, A.E. A Review of Research on Formal Reasoning and Science Teaching, Journal of Research in Science Teaching, 22(7): 569-617. 1985.

[9] Obed, N. Investigating the Nature of Formal Reasoning. Journal of Research in Science Teaching, 34(10): 1067-1081. 1997.

[10] Friedler, Y., R. Nachmias., M.C. Linn. Learning Scientific Reasoning Skills in Microcomputer Laboratories, Journal of Research in Science Teaching 27(2): 173-191. 1990.

[11] Moll, M.B., R.D. Allen. Developing Critical Thinking Skills in Biology. Journal of College Science Teaching, 12(2): 95-98. 1982.

[12] Novak, J.D., J.M. Detloff. Developing Critical Thinking Skills in Community College Students, Journal of College Science Teaching, 18(2): 22-25. 1989.

[13] Statkiewicz, W.R., R.D. Allen. Practice Exercises to Develop Critical Thinking Skills, Journal of College Science Teaching, 12(4): 262-266. 1983.

[14] Zohar, A., P. Tamir. Incorporating Critical Thinking into a Regular High School Biology Curriculum, School Science and Mathematics, 93(3): 136-140. 1993.

[15] Zoller, U. Scaling Up of Higher-Order Cognitive Skills-Oriented College Chemistry Teaching, Journal of Research in Science Teaching, 36(5): 583-596. 1999.

[16] Tittle, P. Critical Thinking: An Appeal to Reason. London: Routledge. 2011.

[17] Black, B. It's Not Like Teaching Other Subjects-The Challenges of Introducing Critical Thinking as Level in England, Research Matters 10: A Cambridge Assessment Publication, 10(1): 2-8. 2010.

[18] Wiyanto., S.E. Nugroho., Hartono. The Scientific Approach Learning: How Prospective Science Teachers Understand about questioning. Journal of Physics: Conference Series, 824(1). 2017.

[19] Aristianti, E., H. Susanto., P. Marwoto. Implementasi Model Pembelajaran Inkuiri Terbimbing Terhadap Kemampuan Pemecahan Masalah dan Komunikasi Ilmiah Siswa SMA. Unnes Physics Education Journal, 7(1): 67-73. 2018.

[20] Habibah, F.N., A.T. Widodo., Jumaeri. Pengembangan Perangkat Pembelajaran Kontekstual Berpendekatan Inkuiri Terbimbing Materi KSP. Journal of Innovative Science Education, 6(1): 66-74. 2017.

[21] Budiarti, S., M. Nuswowati., E. Cahyono. Guided Inquiry Berbantuan E-Modul untuk Meningkatkan Keterampilan Berpikir Kritis. Journal of Innovative Science Education, 5(2): 144151. 2016.

[22] Astuti, H.D., S. Linuwih., P. Marwoto. Keefektifan Pembelajaran Inkuiri Terbimbing Dilengkapi Penilaian Portofolio untuk Meningkatkan Berpikir Kritis Siswa SMA. Unnes Physics Education Journal, 5(1): 82-88. 2016.

[23] Usdalifat, S., A. Ramadhan., S.M. Suleman. Pengaruh Model Pembelajaran Inkuiri Terhadap Kemampuan Berpikir Kritis dan Keterampilan Proses Siswa Pada Mata Pelajaran IPA Biologi Kelas VII SMP Negeri 19 Palu. Jurnal Sains dan Teknologi Tadulako, 5(3): 1-10. 2016.

[24] Banchi, H., R. Bell. The Many Levels of Inquiry. Science and Children. Journal Science and Children. University of Virginia, 2(2): 26-29. 2008.

[25] Dewi, N. L., N. Dantes., I.W. Sadia. Pengaruh Model Pembelajaran Inkuiri Terbimbing Terhadap Sikap Ilmiah dan Hasil Belajar IPA. e-Journal Program Pascasarjana Universitas Pendidikan Ganesha, 3(1): 1-13. 2013.

[26] Zion, M., R. Mendelovici. Moving from Structured to Open Inquiry: Challenges and Limits. Science Education International, 23(4): 383-399. 2012.

[27] Matthew, B.M., I.O. Kenneth. A Study on the Effects of Guided Inquiry Teaching Method on Students Achievement in Logic. International Researchers, 2(1): 134-140. 2013.

[28] Llewellyn, D. Teaching High School Science Through Inquiry and Argumentation. USA: Saga Publication. 2013.

[29] Novak, J.D., D.B. Gowin. Learning How to Learn. Cambridge University Press: Cambridge. 1984.

[30] Buzan, T., B. Buzan. The Mind Map Book: How to Use Radiant Thinking to Maximize Your Brain's Untapped Potential. New York: Plume. 1993.

[31] van Gelder, T.J. Argument Mapping. In Encyclopedia of the Mind, edited by H. Pashler. Thousand Oaks, CA: Sage. 2015. 
[32] Davies, W.M. Concept Mapping, Mind Mapping and Argument Mapping: What are the Differences and Do They Matter? Available from: http://www.tlu.fbe.unimelb.edu.au/teaching_staff/seminar_series/documents/Sem1CMMMAM.pdf. 2010.

[33] Horton, P.B., A.A. McConney., M. Gallo., A.L. Woods., G.J. Senn., D. Hamelin. An Investigation of the Effectiveness of Concept Mapping as an Instructional Tool. Science Education, 77(1): 95111. 1993.

[34] Nesbit, J.C., O.O. Adescope. Learning with Concept and Knowledge Maps: A Meta-analysis. Review of Educational Research, 76(3): 413-448. 2006

[35] Able, W.M., M. Freeze. Evaluation of Concept Mapping in an Associate Degree Nursing Program. Journal of Nursing Education, 45(9): 356-364. 2006.

[36] Briscoe, C., S.U. LaMaster. Meaningful Learning in College Biology Through Concept Mapping. The American Biology Teacher, 53(4): 214-219. 1991.

[37] Kinchin, I.M. If concept mapping is so helpful to learning biology, why aren't we all doing it? International Journal of Science Education, 23(12): 1257-1269. 2001.

[38] Miller, H.R., K.S. McNeal., B.E. Herbert. Inquiry in the Physical Geology Classroom: Supporting Students' Conceptual Model Development. Journal of Geography in Higher Education. 34(4): 595-615. 2010.

[39] Drake, K.N., D. Long. A Comparative Study of Experiential Learning in Two Fourth-Grade Classrooms. Journal of Elementary Science Education, 21(1): 1-16. 2009.

[40] Varma, T., M.J. Volkmann., D.L. Hanuscin. Pre-service Elementary Teachers' Field Experiences in Classrooms Led by Science Specialists. Manuscript submitted for publication. Journal of Science Teacher Education. 2009.

[41] van Gelder, T.J. The Rationale for Rationale. Law, Probability and Risk, 6(1): 23-42. 2007.

[42] Austhink. Austhink Argument Mapping Tutorial. Available from: http://austhink.com/reason/tutorials/Tutorial_1/index.htm. 2008.

[43] Stalheim-Smith, A. Focusing on Active, Meaningful Learning. Idea Paper 34. Manhattan, KS: Kansas State University, Center for Faculty Evaluation and Development. 1998.

[44] Novak, J.D., A.J. Canas. Theoretical Origins of Concept Maps, How to Construct Them and Uses in Education. Journal of Reflecting Education, 3(1): 29-42. 2007.

[45] Liu, M., J.J. Lee., C. Linn. The Effect of Science-Technology-Society Teaching on Students' Attitudes Toward Science, Problem Solving and Certain Aspects of Creative and Critical Thinking Abilities. International Journal of Science Education, 29(11): 1315-1327. 2010.

[46] Heinze-Fry, J.A., J.D. Novak. Concept Mapping Brings Long-term Movement Toward Meaningful Learning. Science Education, 74(4): 461-472. 1990.

[47] Huai, H. Concept Mapping in Learning Biology: Theoretical Review on Cognitive and Learning Styles. Journal of Interactive Learning Research, 8(3/4): 325-340. 1997.

[48] Mason, C.L. Concept Mapping: A Tool to Develop Reflective Science Instruction. Science Education, 76(1): 51-63. 1992.

[49] Angelo, T.A., K.P. Cross. Classroom Assessment Techniques: A Handbook for College Teachers (2nd Ed.). San Francisco: Jossey-Bass. 1993.

[50] Kemmis, S., R. McTaggart. The Action Research Planner. Victoria: Deakin University Press. 1982.

[51] Finken., R.H. Ennis. Illinois Critical Thinking Essay Test. Illinois Critical Thinking Project. Department of Educational Policy Studies University of Illinois. 1993.

[52] Miles, M.B., Huberman, A.M. Qualitative Data Analysis, A Method Sourcebook, Edition 3. USA: Sage Publications. 2014.

[53] Looi, C.K. Interactive Learning Environments for Promoting Inquiry Learning, Journal of Educational Technology Systems, 27(2): 3-22. 1998.

[54] Coffman, M., L. Riggs. The Virtual Vee Map. Journal of College Science Teaching. Vol. 36 No. 1. 2006. 